\title{
PENGUATAN KELEMBAGAAN TPI DALAM MEWUJUDKAN PERIKANAN BERKELANJUTAN DAN BERKEADILAN
}

\author{
Akhmad Solihin, ${ }^{1,2^{*}}$ M. Arsyad Alamin ${ }^{1}$, Isdahartatie ${ }^{1}$ \\ ${ }^{1}$ Pusat Kajian Sumberdaya Pesisir dan Lautan, Institut Pertanian Bogor, Bogor 16127 \\ ${ }^{2}$ Departemen Pemanfaatan Sumberdaya Perikanan, \\ Fakultas Perikanan dan Ilmu Kelautan Institut Pertanian Bogor, Bogor 16680 \\ *Email: akhmad_solihin@pksplipb.ac.id
}

\begin{abstract}
RINGKASAN
Pelabuhan perikanan berperan penting dalam pengelolaan dan pemanfaatan sumberdaya ikan, kegiatan praproduksi, produksi, pengolahan, pemasaran ikan dan pengawasan sumberdaya ikan. Namun demikian, keberadaan sistem pelelangan di pelabuhan perikanan tersebut dihadapkan pada kompleksitas permasalahan yang tidak hanya menghambat perekonomian daerah, akan tetapi juga mengganggu keberlanjutan perikanan. Beberapa permasalahan tersebut antara lain kuatnya peran patronase nelayan dan pembeli yang tidak tercatat di pelabuhan perikanan, ketiadaan kepemilikan modal para pelelang ikan, dan sarana prasarana pelabuhan perikanan yang sangat minim. Kabupaten Tangerang yang memiliki potensi perikanan mengoptimalkan peran dan fungsi Tempat Pelelangan Ikan (TPI), salah satunya adalah optimalisasi pelelangan ikan di Cituis. Tujuan penelitian ini yaitu: (1) menganalisis isu dan permasalahan kelembagan TPI di Pangkalan Pendaratan Ikan (PPI) Cituis, dan (2) menyusun rekomendasi kebijakan dalam penguatan peran kelembagaan TPI. Metode yang digunakan adalah Logical Framework. Analysis. Permasalahan utama di TPI Cituis adalah terganggunya pelelangan ikan, yang disebabkan oleh kemampuan daya beli pedagang kecil, sistem lelang di hutang, hubungan sistem langgan, dan minimnya dana talangan. Oleh karena itu diperlukan penguatan fungsi kelembagaan TPI, penguatan peran langgan, peningkatan fasilitas pelabuhan perikanan, dan penegakan hukum.
\end{abstract}

Kata kunci: tempat pelelangan ikan, kelembagaan, perikanan berkelanjutan

\section{PERNYATAAN KUNCI}

- Kelembagaan Tempat Pelelangan Ikan (TPI) yang berperan dalam menciptakan kepastian dan stabilitas harga tidak berperan optimal karena terkendala pola hubungan patron-klien antara nelayan sebagai klien dengan pemilik modal sebagai patron.

- Kegagalan TPI tidak hanya mengakibatkan kemiskinan nelayan yang disebabkan ketidakadilan harga pasar, akan tetapi juga mengakibatkan kegagalan dalam pengelolaan perikanan karena lemahnya sistem pendataan pendaratan ikan.

- Aktivitas pelelangan ikan menjadi indeks kinerja Pangkalan Pendaratan Ikan (PPI) di Kabupaten Tangerang. 


\section{REKOMENDASI KEBIJAKAN}

- Penguatan fungsi TPI sebagai lembaga pemasaran yang menjamin stabilitas harga, sehingga peran dan fungsinya harus dikuatkan dengan cara pemberian pelatihan terhadap staf pengelola TPI, dan penataan sistem yang berkeadilan dan berkelanjutan.

- Penguatan peran langgan atau para pemilik modal (patron) dalam pengelolaan kelembagaan TPI, karena pola hubungan patron-klien antara pemilik modal dengan nelayan sudah terjalin kuat melalui hutangpiutang yang nilainya cukup besar.

- Pembangunan fasilitas PPI guna mendukung pelelangan ikan, yaitu pengerukan kolam pelabuhan, pembangunan talud, turap, penghalang angin, pemecah gelombang, perluasan lahan, penambahan fasilitas daya tampung air, dan peningkatan daya listrik.

- Penegakan hukum secara serius yang dituangkan dalam Peraturan Daerah Kabupaten Tangerang Nomor 2 Tahun 2012 tentang Pengelolaan dan Penyelenggaraan Tempat Pelelangan Ikan.

\section{PENDAHULUAN}

Pelabuhan Perikanan, termasuk didalamnya Pangkalan Pendaratan Ikan (PPI), adalah pusat ekonomi perikanan yang diarahkan untuk menjadi kawasan andalan yang strategis, produktif, dan cepat tumbuh sebagai sentra produksi dan sentra industri bagi pengembangan ekonomi terpadu di wilayah pesisir (Lubis, 2012). Dilihat dari fungsinya, Pangkalan Pendaratan Ikan merupakan prasarana penangkapan yang diperuntukkan bagi semua pengguna jasa/stakeholders yang bekerja di sektor perikanan, terutama untuk nelayan skala usaha kecil dalam rangka mendukung pengembangan ekonomi perikanan, pengembangan wilayah dalam memberikan pelayanan umum dan jasa untuk memperlancar kegiatan usaha perikanan serta mendukung pelaksanaan program otonomi daerah.

Dengan demikian, keberadaan PPI mutlak diperlukan untuk menunjang aktivitas perikanan dalam kegiatan pengelolaan dan pemanfaatan sumberdaya ikan, kegiatan praproduksi, produksi, pengolahan, pemasaran ikan dan pengawasan sumberdaya ikan. Oleh karena itu, pembangunan PPI perlu dilakukan. Pangkalan Pendaratan Ikan seringkali menjadi barometer majunya perikanan di suatu daerah atau wilayah karena kita dengan cepat melihat perkembangan unsur-unsur yang berperan dalam usaha perikanan seperti ikan, kapal perikanan, alat penangkapan ikan, nelayan, pengusaha perikanan dan pasar ikan.

Salah satau fasilitas fungsional yang harus ada dalam suatu PPI adalah Tempat Pelelangan Ikan (TPI). Keberadaan fasilitas TPI berfungsi agar nilai hasil tangkapan tetap tinggi serta mutu hasil tangkapan dapat tetap terjaga. Pelelangan adalah kegiatan pemasaran yang mempertemukan penjual dan pembeli. Dalam hal ini nelayan sebagai penjual hasil tangkapan, diwakili oleh petugas lelang. Pelelangan ikan merupakan salah satu mata rantai dari kegiatan usaha penangkapan. Pada pemasaran ikan secara lelang yang terorganisir dengan baik, harga tidak ditentukan oleh penjual dan pembeli saja namun juga secara bersama dengan memperhatikan mutu ikan. Nilai jual yang diperoleh nelayan akan lebih besar melalui proses lelang dibandingkan bila nelayan berhadapan langsung satu persatu dengan pembeli. Kegiatan pelelangan berhubungan atau berpengaruh 
terhadap pendapatan atau kesejahteraan para nelayan/pengusaha penangkapan (Pane, 2010; Wibisono, 2005). Agar penjualan hasil tangkapan tetap menguntungkan, maka proses pelelangan haruslah dilakukan secara berkelanjutan.

Sistem pelelangan di pelabuhan perikanan/ pangkalan pendaratan ikan yang terorganisir akan menguntungkan bagi nelayan dan pedagang. Pada proses pelelangan, antara penjual (diwakili petugas pelelangan) dan pembeli, bertemu dan bertransaksi secara langsung untuk mendapatkan harga keseimbangan. Selain itu, proses pelelangan juga membentuk harga ikan sesuai transparansi permintaan dan penawaran pasar. Proses pelelangan ikan sangat membantu dalam mendorong nelayan/pengusaha penangkapan untuk menjaga dan menjamin mutu/ kualitas ikan yang akan dilelang.

Pada proses pelelangan yang baik mutu hasil tangkapan yang akan dilelang akan selalu dikontrol. Ikan dengan kualitas baik akan lebih laku dan memiliki harga jual yang lebih tinggi, sedangkan ikan dengan kualitas rendah akan mempunyai nilai jual yang rendah pula. Dalam transaksi langsung per-orang, nelayan selain berhadapan dengan tekanan pembeli, juga berhadapan dengan tekanan mutu ikan yang menurun dalam fungsi waktu (Pane, 2010).

Permasalahan di atas terjadi juga di TPI Cituis, yang berdampak terhadap lemahnya statistik perikanan yang digunakan dalam kebijakan penetapan kapasitas tangkap (jumlah kapal dan alat tangkap yang digunakan). Kegagalan penetapan kebijakan tersebut akan berdampak terhadap keberlanjutan perikanan, yang akhirnya berdampak juga terhadap kesejahteraan pelaku usaha perikanan, khususnya nelayan. Permasalahan lain yang kruisal adalah fasilitas sarana dan prasarana PPI Cituis yang sangat minim, sehingga tidak optimal dalam memberikan pelayanannya.

Berdasarkan hal tersebut, fungsi TPI sangat kuat dalam mensejahterakan pelaku usaha perikanan, khsusunya nelayan. Oleh karena itu, sebagai daerah yang memiliki potensi besar, Kabupaten Tangerang sudah seyogyanya mengoptimalkan peran dan fungsi TPI tersebut. Salah satu upayanya adalah optimalisasi pelelangan ikan di Cituis. PPI Cituis merupakan salah satu PPI sentra sebagai Unit Pelaksana Teknis Daerah (UPTD) di Kabupaten Tangerang, yang memiliki pelayanan terbaik kepada nelayan, seperti pemberian dana paceklik, dana sosial, sumbangan kematian dan simpan pinjam serta menyediakan akses perbankan. Adapun tujuan dari kegiatan "Pengelolaan Fasilitas Tempat Pelelangan Ikan (TPI) Cituis Pada PPI Cituis, Kabupaten Tangerang", adalah: (1) memetakan isu dan permasalahan kelembagan Tempat Pelelangan Ikan di PPI Cituis, dan (2) menyusun rekomendasi kebijakan dalam penguatan peran kelembagaan Tempat Pelelangan Ikan di PPI Cituis.

\section{SITUASI TERKINI}

Tempat Pelelangan Ikan (TPI) sampai saat ini berfungsi menciptakan keseimbangan harga komoditas ikan yang dilelang. Hal ini dikarenakan TPI diberikan mandat untuk menjamin harga yang optimal kepada nelayan sehingga dapat mensejahterakan mereka. Namun demikian, fungsi TPI tersebut dihadapkan pada berbagai permasalahan yang mengakibatkan fungsi dan perannya tidak optimal.

Berdasarkan hasil kunjungan lapangan di TPI Cituis, ditemukan tiga kelompok permasalahan, yaitu: Pertama, ketersediaan dan kualitas ikan yang 
rendah. Masalah pertama ini terkait dengan ketiadaan ikan yang dilelang karena adanya pola hubungan patron-klien sehingga ikan dijual langsung oleh nelayan kepada langgan (pemilik modal). Selain itu, masalah komoditas ikan juga terkait dengan kualitas ikan yang dilelang yang sudah membusuk. Kedua, sarana dan prasarana Pangkalan Pendaratan Ikan yang kurang memadai. Masalah kedua ini terkait dengan sarana dan prasarana di Pangkalan Pendaratan Ikan Cituis dan khususnya Tempat Pelelangan Ikan yang kurang memadai sehingga mengakibatkan terganggunya pelayanan dan jaminan komoditas ikan yang baik. Ketiga, tidak berjalannya sistem lelang dengan baik. Masalah ketiga ini terkait dengan kuatnya peran para pemilik modal sehingga ikan tidak didaratkan di PPI dan tidak dilelang di TPI. Selain itu, sistem lelang dihadapkan pada ketiadaan kepemilikan uang tunai (cash) para pelelang itu sendiri (pembeli ikan), dimana ikan dibayar setelah ikan yang diperoleh lelang laku terjual. Dengan kata lain, para pihak yang ikut lelang tidak memiliki modal. Lebih parahnya lagi, ditemukan pelelangan semu, dimana para pihak yang ikut lelang mempermainkan harga ikan. Hal ini dikarenakan, posisi pembeli dan penjual yang tidak seimbang.

Kelembagaan Tempat Pelelangan Ikan di seluruh kelas pelabuhan perikanan secara hukum sudah sepenuhnya menjadi kewenangan Pemerintah Kabupaten/Kota sesuai dengan Undang-Undang Nomor 23 Tahun 2014 tentang Pemerintahan Daerah. Sementara untuk pengelolaan pelabuhan perikanan, mulai dari kelas Pelabuhan Perikanan Samudera (PPS), Pelabuhan Perikanan Nusantara (PPN), dan sebagian Pelabuhan Perikanan Pantai (PPP) menjadi kewenangan Pemerintah Pusat, dan untuk sebagian Pelabuhan Perikanan Pantai (PPP) dan
Pangkalan Pendaratan Ikan (PPI) menjadi kewenangan Pemerintah Provinsi.

\section{ANALISIS DAN ALTERNATIF SOLUSI}

Kurang optimalnya Tempat Pelelangan Ikan (TPI) di Kabupaten Tangerang mengganggu aktivitas pencatatan data ikan yang didaratkan yang berujung pada gagalnya penetapan kebijakan berbasiskan ketersediaan data. Sementara itu nelayan dirugikan oleh ketidakjelasan dan ketidakstabilan harga pasar. Kesejahteraan nelayan di TPI Cituis yang lebih aktif dibandingkan dengan TPI lainnya belum dapat dikatakan sejahtera karena rata-rata pendapatan nelayan setempat berkisar Rp 20.000- 35.000 rupiah per hari dengan jumlah tanggungan keluarga rata-rata lebih dari 5 orang.

Dalam memenuhi kebutuhan nelayan sebagai pengguna jasa pelabuhan, sarana dan prasarana yang ada belum dikatakan baik seperti akses jalan menuju pelabuhan dirasakan sangat jauh dari jalan utama dengan kondisi jalan rusak dan becek, maka perlu adanya perbaikan oleh pihak pengelola agar para pengguna jasa pelabuhan dapat memperoleh kepuasan dalam pelayanan yang diberikan oleh pelabuhan tersebut.

Isu permasalahan yang terkait dengan peningkatan fungsi dan peran TPI Cituis merupakan bagian penting yang harus diperhatikan dalam penelitian ini. Selain dari hasil analisis survey lapangan dan data sekunder, isu dan permasalahan juga diperoleh dari hasil wawancara mendalam (deep interview). Isu dan permasalahan yang terkait dengan fungsi dan peran TPI akan digambarkan dalam diagram hubungan akar masalah. Diagram akar masalah tersebut akan 
dianalisis melalui pendekatan Analisis Kerangka Logis atau Logical Framework. Analysis (LFA), yaitu instrumen analisis, presentasi dan pengelolaan yang dapat membantu perencana untuk menganalisis situasi eksisting, membangun hirarki logika dari tujuan yang akan dicapai, mengidentifikasi resiko potensial yang dihadapi dalam pencapaian tujuan dan hasil, membangun cara untuk melakukan monitoring dan evaluasi terhadap tujuan (purpose) dan hasil (outputs), menyajikan ringkasan aktivitas suatu kegiatan serta membantu upaya monitoring selama pelaksanaan implementasi proyek (ADB, 1998).

Isu dan permasalahan peningkatan fungsi dan peran TPI Cituis, yaitu: (1) kegiatan lelang terganggu, (2) pendangkalan kolam pelabuhan, (3) talud rusak, (4) belum ada turap, (5) tidak ada penghalang angin, (6) break water tidak memadai
(7) masih ada tengkulak, (8) kualitas ikan yang dilelang rendah, (9) pembayaran hasil lelang tidak kontan, (10) dana talangan minim, (11) sanksi perda lelang tidak berjalan, (12) keterbatasan lahan, (13) air bersih masih kurang, (14) listrik kurang, dan (15) tekanan peningkatan retribusi.

Isu permasalahan yang terkait dengan fungsi dan peran TPI digambarkan dalam diagram hubungan isu permasalahan (Gambar 1). Diagram hubungan isu permasalahan tersebut merupakan hasil analisis melalui proses partisipatif dari stakeholders melalui wawancara mendalam dan pengamatan di lapangan.

Gambar 1 menunjukkan kompleksitas isu permasalahan yang terkait fungsi dan peran TPI. Sebagian isu dan masalah tersebut merupakan masalah yang menjadi penyebab dari munculnya isu dan masalah yang lain. Makin tinggi interaksi

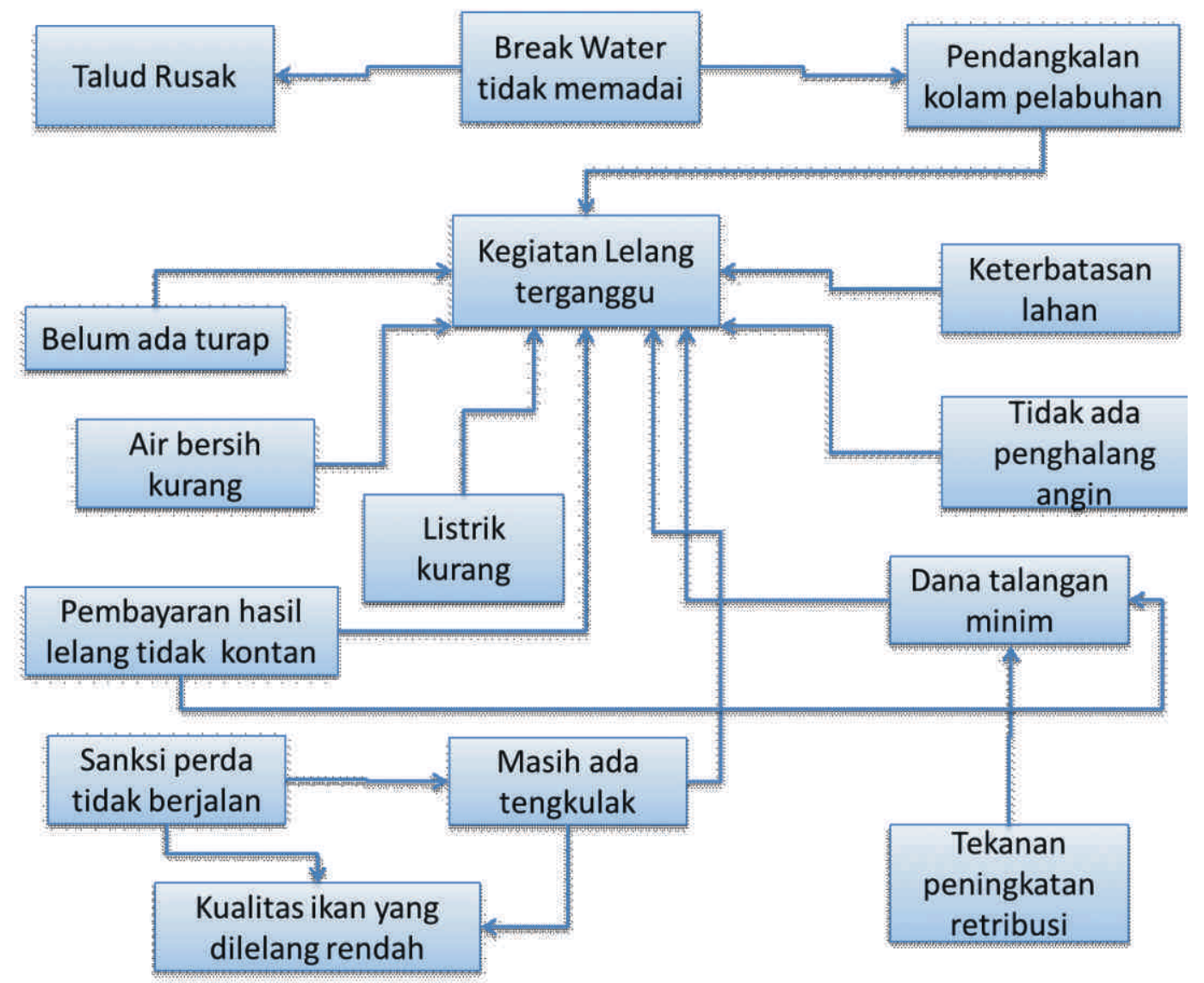

Gambar 1. Hubungan LFA dari isu permasalahan fungsi dan peran TPI Cituis 
Tabel 1 Pengelompokan hubungan isu permasalahan fungsi dan peran TPI Cituis

\begin{tabular}{|c|c|c|c|c|c|}
\hline No & Isu Permasalahan & $\mathrm{Ca}\left(\mathrm{x}^{2}\right)$ & $\begin{array}{l}\text { Eff } \\
\left(x^{1}\right)\end{array}$ & Skor & Grade \\
\hline 1 & Kegiatan lelang terganggu & 0 & 9 & 9 & $\mathrm{I}$ \\
\hline 2 & Pendangkalan Kolam Pelabuhan & 2 & 1 & 3 & III \\
\hline 3 & Talud rusak & 2 & 0 & 2 & III \\
\hline 4 & Belum ada turap & 2 & 0 & 2 & III \\
\hline 5 & Tidak ada penghalang angin & 2 & 0 & 2 & III \\
\hline 6 & Break water tidak memadai & 4 & 0 & 4 & II \\
\hline 7 & Masih ada tengkulak & 4 & 1 & 5 & II \\
\hline 8 & Kualitas ikan yang dilelang rendah & 0 & 2 & 2 & III \\
\hline 9 & Pembayaran hasil lelang tidak kontan & 4 & 0 & 4 & II \\
\hline 10 & Dana talangan minim & 2 & 2 & 4 & II \\
\hline 11 & Sanksi perda lelang tidak berjalan & 4 & 0 & 4 & II \\
\hline 12 & Keterbatasan lahan & 2 & 0 & 2 & III \\
\hline 13 & Air bersih masih kurang & 2 & 0 & 2 & III \\
\hline 14 & Listrik kurang & 2 & 0 & 2 & III \\
\hline 15 & Tekanan peningkatan retribusi & 2 & 0 & 2 & III \\
\hline
\end{tabular}

Keterangan:

$\mathrm{Ca}=$ Causatif (Penyebab)

$\mathrm{Ef}=$ Effect (Akibat/Dampak)

antar masalah, menunjukkan makin tingginya kerumitan upaya penyelesaian masalah tersebut. Untuk dapat memahami sejauh mana isu dan permasalahan tersebut berkembang, maka dapat dilihat dari intensitas interaksi. Pengelompokan isu dan masalah yang disarikan pada Tabel 1 ditetapkan berdasarkan isu permasalahan yang menjadi penyebab (causa) terhadap isu permasalahan lain yang terdampak (effect) akan dinilai 2, sementara isu permasalahan yang terdampak diberi nilai 1 . Hasil setiap isu permasalahan dijumlahkan, yang kemudian menghasilkan skor 1-3 (grade III), skor 4-6 (grade II), dan skor 7-9 (grade I).

Berdasarkan analisis LFA sebagaimana yang disajikan pada Tabel 1, diketahui bahwa ada 15 isu permasalahan yang menjadi penyebab bagi timbulnya masalah lain. Isu permasalahan yang seharusnya mendapat perhatian besar dalam fungsi dan peran TPI Cituis adalah break water kurang, masih ada tengkulak, sistem lelang di hutang, dan sanksi perda lelang tidak berjalan. Sedangkan masalah lain yang banyak terjadi akibat permasalahan yang ada adalah kegiatan lelang terganggu. Kelompok masalah yang berperan besar sebagai penyebab dan akibat yaitu kegiatan lelang terganggu.

Untuk menentukan urutan permasalahan yang akan diprioritaskan dalam penyelesaiannya perlu dilakukan pengelompokan isu dan masalah yang ada. Secara lebih jelas, pengelompokan isu permasalahan fungsi dan peran TPI Cituis 
Tabel 2. Pengelompokan Isu Permasalahan fungsi dan peran TPI Cituis

\begin{tabular}{lll}
\hline No & \multicolumn{1}{c}{ Prioritas } & Jenis Masalah \\
\hline 1 & I (Skor 7-9) & Kegiatan lelang terganggu \\
\hline 2 & II (Skor 4-6) & $\begin{array}{l}\text { Masih ada tengkulak, Break water tidak memadai, Pembayaran hasil lelang } \\
\text { tidak kontan, Dana talangan minim, Sanksi perda lelang tidak berjalan }\end{array}$ \\
& & Pendangkalan Kolam Pelabuhan, Talud rusak, Belum ada turap, Tidak ada \\
& Penghalang angin, Kualitas ikan yang dilelang rendah, Keterbatasan lahan, \\
& & Air bersih masih kurang, Listrik kurang, Tekanan peningkatan retribusi \\
& &
\end{tabular}

disajikan pada Tabel 2. Berdasarkan pengelompokan isu permasalahan tersebut, masalah TPI Cituis tidak beroperasi perlu mendapat perhatian yang serius. Hal ini dikarenakan faktor tersebut berdampak pada keberlanjutaan pengelolaan TPI Cituis.

Hasil pengelompokan sebagaimana disajikan pada Tabel 2 menjadi bahan dalam penyusunan alternatif solusi dan strategi. Strategi pengembangan harus dilakukan dari beberapa sisi, salah satunya berdasarkan dari sudut pandang perkembangan permasalahan yang terjadi. Hal ini dikarenakan permasalahan yang ada dapat menjadi inbibitor (penghalang) bagi terjadinya sinergitas pembangunan di masa mendatang. Sisi permasalahan harus dipandang sebagai sesuatu yang harus diupayakan untuk diminimalisir agar manfaat yang ada dapat dimaksimumkan. Untuk itu setiap permasalahan yang terjadi harus menjadi komponen penting untuk diantisipasi dalam merumuskan penyusunan kebijakan.

Berdasarkan isu permasalahan yang terkait dengan penguatan fungsi dan peran TPI Cituis, maka disusun beberapa alternatif strategi yang dapat dilakukan dalam rangka untuk memecahkan permasalahan tersebut. Secara lebih jelas, alternatif strategi pemecahan berdasarkan isu permasalahan fungsi dan peran TPI Cituis disajikan pada Tabel 3 .
Berdasarkan alternatif strategi pada Tabel 4 disajikan empat strategi yang perlu dilakukan dalam mewujudkan kelembagaan TPI dalam mewujudkan perikanan yang berkelanjutan dan berkeadilan. Adapun keempat hal tersebut, yaitu: Pertama, penguatan fungsi dan peran TPI. Strategi tersebut sesuai dengan (Adrianto et al., 2006) yang mengungkapkan bahwa dalam rangka pengembangan TPI masa depan, TPI tidak hanya berperan sebagai lembaga dengan single function sebagai pelaksana pelelangan ikan, namun TPI mampu juga berperan sebagai pusat pelelangan ikan dan penyedia jasa pelelangan ikan (Gambar 2). Keberadaan TPI di Indonesia umumnya dan Cituis khususnya, hanya melayani jasa lelang. Padahal kelembagaan TPI bisa memberikan pelayanan lebih luas, yaitu sebagai bursa komoditas, mitra lembaga keuangan dan usaha transportasi.

Kedua, sinergisme kelembagaan formal dan non-formal dengan cara penguatan peran para pemilik modal (langgan). Kegagalan sistem lelang di TPI Cituis disebabkan karena kuatnya pola patron-klien antara nelayan dengan pembeli ikan yang menjadi penjamin bagi nelayan dalam menyediakan modal usaha. Akibatnya sistem pelelangan ikan tidak berjalan optimal. Oleh karena itu diperlukan sinergisme kelembagaan non-formal (patron-klien) dengan kelembagaan 
Tabel 3. Isu Permasalahan dan Alternatif Strategi Pemecahan

\begin{tabular}{|c|c|c|c|c|}
\hline \multirow[t]{2}{*}{ No. } & \multirow[t]{2}{*}{ Akar Masalah } & \multicolumn{2}{|c|}{ Prioritas Strategi } & \multirow[t]{2}{*}{ Alternatif Solusi } \\
\hline & & Sekuen & Prioritas & \\
\hline \multicolumn{5}{|l|}{ Prioritas I } \\
\hline 1 & $\begin{array}{l}\text { Kegiatan lelang } \\
\text { terganggu }\end{array}$ & I & 1 & $\begin{array}{l}\text { - Penguatan } \\
\text { fungsi TPI }\end{array}$ \\
\hline \multicolumn{5}{|l|}{ Prioritas II } \\
\hline 2 & $\begin{array}{l}\text { Masih ada } \\
\text { tengkulak, }\end{array}$ & II & 1 & $\begin{array}{l}\text { Sinergisasi } \\
\text { kelembagaan } \\
\text { formal dan } \\
\text { kelembagaan } \\
\text { non-formal }\end{array}$ \\
\hline 3 & $\begin{array}{l}\text { Break water tidak } \\
\text { memadai }\end{array}$ & II & 2 & $\begin{array}{l}\text { - Peningkatan } \\
\text { fasilitas PPI }\end{array}$ \\
\hline 4 & $\begin{array}{l}\text { Pembayaran hasil } \\
\text { lelang tidak kontan }\end{array}$ & II & 3 & $\begin{array}{l}\text { - Penguatan } \\
\text { fungsi TPI }\end{array}$ \\
\hline 5 & $\begin{array}{l}\text { Dana talangan } \\
\text { minim, }\end{array}$ & II & 4 & $\begin{array}{ll}\text { - } & \text { Penguatan } \\
\text { fungsi TPI } \\
\text { - Sinergisasi } \\
\text { kelembagaan } \\
\text { formal dan } \\
\text { kelembagaan } \\
\text { non-formal }\end{array}$ \\
\hline 6 & $\begin{array}{l}\text { Sanksi perda lelang } \\
\text { tidak berjalan }\end{array}$ & II & 5 & $\begin{array}{ll}\text { - } & \text { Penguatan } \\
\text { fungsi TPI } \\
\text { - Sinergisasi } \\
\text { kelembagaan } \\
\text { formal dan } \\
\text { kelembagaan } \\
\text { non-formal } \\
\text { - Penegakan } \\
\text { hukum } \\
\end{array}$ \\
\hline
\end{tabular}

formal (TPI) dalam rangka saling menguatkan para pelaku usaha perikanan. Kusuma (2014) menyatakan bahwa perubahan sistem jual beli ikan yang tadinya bersentral pada kehendak pedagang, dalam hal ini pembeli ikan langsung dari nelayan, menjadi kesepakatan harga antara nelayan dengan tengkulak ikan dengan sistem lelang, maka hal itu membawa perubahan pada tingkat harga jual hasil nelayan. Hal ini bisa diindikasikan harga jual menjadi bersaing dan tidak semata-mata ditentukan oleh pembeli ikan dan hal tersebut membawa perubahan dalam pendapatan nelayan. Dengan demikian, para pemilik modal dalam kelembagaan non-formal jangan diposisikan sebagai musuh melainkan sebagai mitra utama kelembagaan formal (TPI).

Ketiga, peningkatan fasilitas Pangkalan Pendaratan Ikan Cituis. Pembangunan sarana dan prasarana pelabuhan perikanan dilakukan sesuai Peraturan Menteri Kelautan dan Perikanan Nomor PER.08/MEN/2012 tentang Kepelabuhanan Perikanan. Fasilitas pelabuhan 
Tabel 3. Isu permasalahan dan alternatif strategi pemecahan

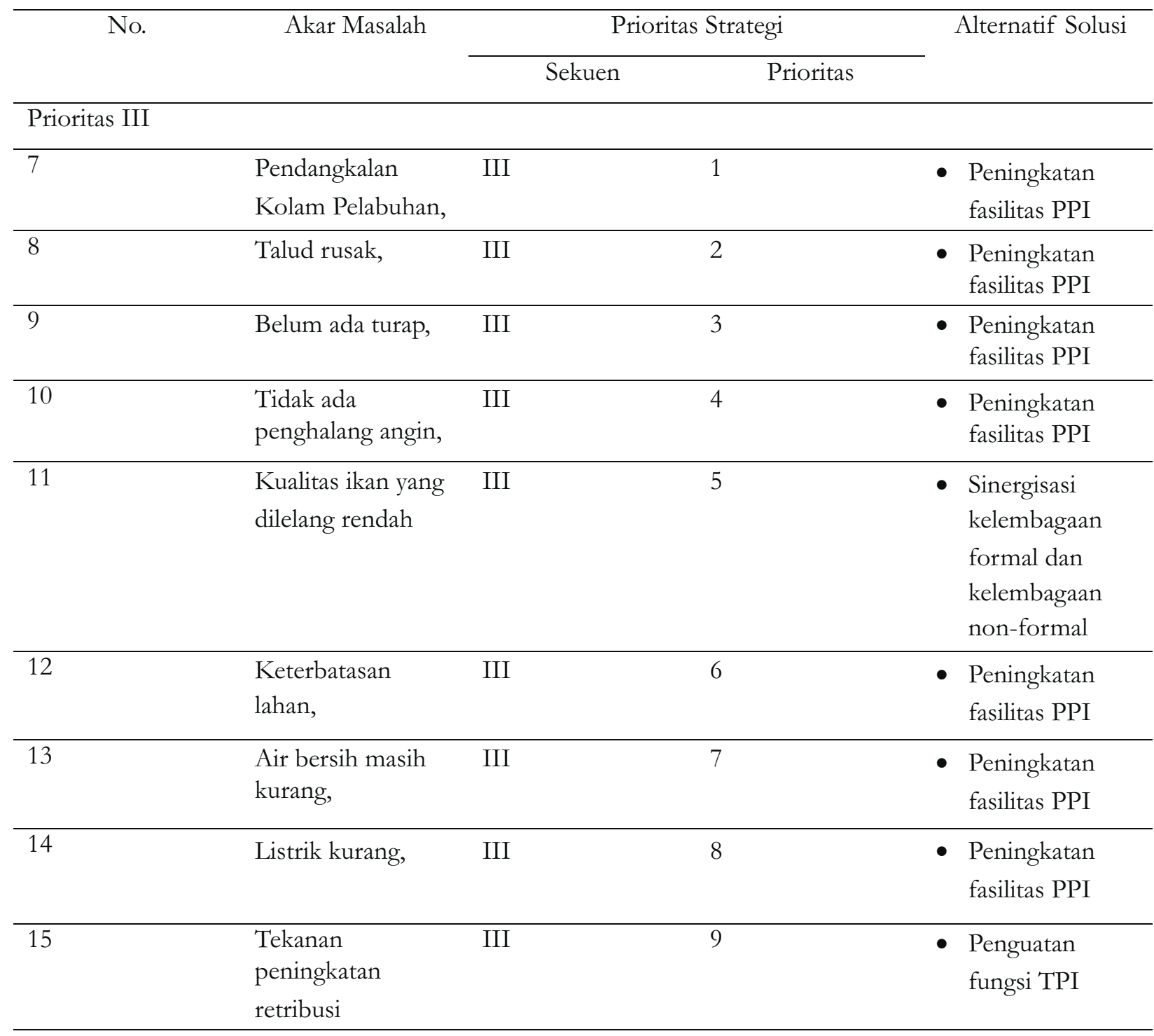

perikanan yang diperlukan dalam rangka menunjang fungsi pelabuhan sebagaimana Pasal 4 ayat (1) Permen K N N mor PER.08/MEN/2012, yaitu terdiri dari: fasilitas pokok, fasilitas fungsional, dan fasilitas penunjang. Fasilitas pokok terdiri atas: (a) penahan gelombang (breakwater), turap (revetment), dan groin; (b) dermaga; (c) jetty; (d) kolam pelabuhan; (e) alur pelayaran; (f) jalan komplek dan drainase; dan (g) lahan, baik untuk perkantoran, usaha perikanan maupun perparkiran. Fasilitas fungsional terdiri atas: (a) tempat pemasaran ikan (TPI); (b) navigasi pelayaran dan komunikasi seperti telepon, internet, radio komunikasi, rambu-rambu, lampu suar, dan menara pengawas; (c) air bersih, instalasi Bahan Bakar Minyak (BBM), es, dan instalasi listrik, (d) tempat pemeliharaan kapal dan alat penangkapan ikan seperti dock/slipway, bengkel dan tempat perbaikan jaring, (e) tempat penanganan dan pengolahan hasil perikanan seperti transit sheed dan laboratorium pembinaan mutu, (f) perkantoran seperti kantor administrasi pelabuhan, pos pelayanan terpadu, dan perbankan, (g) transportasi seperti alat-alat angkut ikan, (h) kebersihan dan pengolahan limbah, seperti 


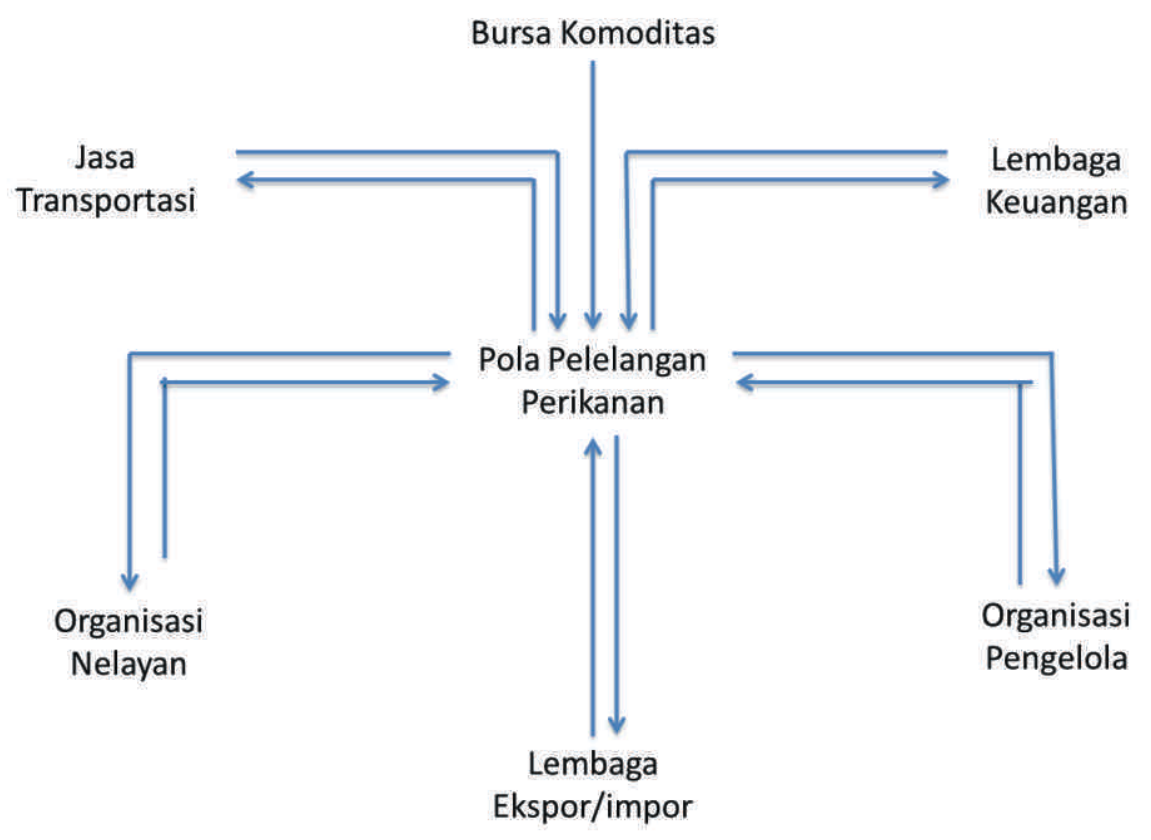

Gambar 2. Pola pengembangan TPI (Adrianto et al. 2006)

Instalasi Pengolahan Air Limbah (IPAL)serta Tempat Pembuangan Sementara (TPS), dan (i) pengamanan kawasan seperti pagar kawasan. Fasilitas penunjang terdiri atas: (a) balai pertemuan nelayan, (b) mess operator, (c) wisma nelayan, (d) fasilitas sosial dan umum seperti tempat peribadatan dan Mandi Cuci Kakus (MCK), (e) pertokoan, dan (f) pos jaga. Sementara itu, fasilitas yang harus ada pada pelabuhan perikanan meliputi: (a) fasilitas pokok terdiri dari: lahan, dermaga, kolam pelabuhan, jalan komplek dan drainase, (b) fasilitas fungsional terdiri dari: kantor administrasi pelabuhan, TPI, suplai air bersih, dan instalasi listrik, (c) fasilitas penunjang terdiri dari pos jaga dan MCK.

Keempat, penegakan hukum terhadap nelayan yang tidak mendaratkan ikan di PPI Cituis. Perahu-perahu nelayan umumnya tidak mendaratkan ikan di PPI, karena kuatnya pola hubungan patron-klien dan keterbatasan pasar dalam menyerap ikan yang dilelang. Hal tersebut diperparah dengan minimnya sarana dan prasarana pelabuhan perikanan. Oleh karena itu, untuk menghidupkan kembali fungsi dan peran TPI diperlukan juga sosialisasi dan penegakan hukum yang dituangkan dalam Peraturan Daerah Kabupaten Tangerang Nomor 8 tahun 2012 tentang Pengelolaan dan Penyelenggaraan Tempat Pelelangan Ikan. Berdasarkan Pasal 10 ayat (1), apabila setiap ikan hasil tangkapan yang tidak diperjualbelikan secara lelang di TPI, maka akan dikenakan pidana kurungan 6 (enam) bulan atau denda paling banyak Rp 50.000.000.

Berdasarkan uraian di atas terlihat bahwa kelembagaan TPI Cituis hanya melayani jasa lelang yang dihadapakan pada berbagai permasalahan, seperti ketidakberdayaan menghadapi system langgan, fasilitas sarana dan prasarana yang kurang memadasi, serta ketiadaan modal para pembeli ikan. Oleh karena itu perlu sinergisme kelembagaan formal (TPI) dengan kelembagaan non-formal (system langgan/ patron-klien), dimana para pemilik modal yang menjadi mitra utama nelayan dilibatkan dalam kepengurusan Tempat Pelelangan Ikan. 


\section{REFERENSI}

Adrianto, L., Solihin, A., Dyah, S., Dwiyana, E. 2006. Panduan Kelembagaan Tempat Pelelangan Ikan. Direktorat Jenderal Pengolahan dan Pemasaran hasil Perikanan-Kementerian Kelautan dan Perikanan.

[ADB] Asian Development Bank. 1998. The conceptual framework and interpretations presented in this guide are the views of the authors and not necessarily those of the Asian Development Bank. ADB Publication.

Kusuma, H.S. 2014. Dampak Tempat Pelelangan Ikan (TPI) terhadap Kehidupan Sosial Ekonomi dan Budaya Masyarakat Nelayan di Desa Bajomulyo Kecamatan Juwana Kabupaten Pati. Jurnal Ilmiah Pendidikan Sejarah IKIP Veteran Semarang, Vol. 02.
No. 1, Nopember 2014: halaman 103-113.

Lubis, E. 2012. Pelabuhan Perikanan. IPB Press. Bogor.

Pane, A.B. 2010. Penganalisaan Hasil Tangkapan bagi Pengembangan Pelabuhan Perikanan. FPIK-IPB.

Peraturan Daerah Kabupaten Tangerang Nomor 2 Tahun 2012 tentang Pengelolaan dan Penyelenggaraan Tempat Pelelangan Ikan

Undang-Undang Nomor 23 Tahun 2014 tentang Pemerintahan Daerah

Wibisono, W. 2005. Peran dan Strategi Koperasi Perikanan dalam Menghadapi Tantangan Pengembangan TPI dan PPI Di Indonesia Terutama Di Pulau Jawa. Makalah dalam Semiloka Internasional tentang Revitalisasi Dinamis Pelabuhan Perikanan dan Perikanan Tangkap Di Pulau Jawa dalam Pembangunan Perikanan Indonesia, Bogor. 